\title{
Síndromes motoras correlacionadas a ELA
}

\section{Marco Orsini, Osvaldo JM Nascimento}

Serviço de Neurologia - UFF

As doenças do neurônio motor são um desafio diagnóstico até para os neurologistas mais experientes. A esclerose lateral amiotrófica (ELA) é o protótipo dessas doenças. Seu diagnóstico é sempre complicado, não só pelo prognóstico sombrio que carrega, mas pelo número de doenças que podem mimetizá-la. Nessa aula veremos as doenças do neurônio motor mais freqüentemente vistas na prática clínica. Motoneuronopatia é um termo genérico utilizado para incluir um grupo de doenças degenerativas caracterizadas pelo comprometimento primariamente do corpo celular do motoneurônio (neurônios motores corticais, do tronco cerebral e espinhais (segundo neurônio). Na infância a principal forma de motoneuronopatia é a amiotrofia espinhal progressiva (AEP), uma doença de herança autossômica recessiva com grande variabilidade quanto a época de início e gravidade do comprometimento motor . A poliomielite se caracteriza por paralisia flácida assimétrica dos membros decorrente de processo infeccioso viral acometendo as células do corno anterior da medula espinhal. Devido a vacinação em massa da população contra o poliovírus, casos novos da doença não têm sido registrados. No entanto, na vida adulta alguns pacientes com seqüela de poliomielite desenvolvem uma piora lentamente progressiva do quadro motor caracterizando a síndrome pós-pólio. As quatro principais síndromes clínicas de início na vida adulta incluídas dentro das motoneuronopatias, também conhecidas como doenças do neurônio motor (DNM), são: atrofia muscular progressiva (AMP), esclerose lateral primária (ELP), paralisia bulbar progressiva (PBP) e esclerose lateral amiotrófica (ELA). Existem também outras formas menos freqüentes de DNM como as Amiotrofias Monomélicas Benignas e as Neuropatias Motoras Multifocais. O diagnóstico 
eletrofisiológico das doenças do neurônio motor se baseia na demonstração de sinais de anormalidades neurogênicas difusas, incluindo desnervação ativa e reinervação crônica sem outra explicação como na presença de polirradiculopatias ou polineuropatias. Não há como diferenciar com precisão as diferentes formas de doença do neurônio motor apenas por meios eletrofisiológicos. Correlação clínica é sempre importante para o diagnóstico diferencial. 